AperTO - Archivio Istituzionale Open Access dell'Università di Torino

\title{
Functional identification of bovine mammary epithelial stem/progenitors cells
}

\section{This is the author's manuscript}

Original Citation:

Availability:

This version is available http://hdl.handle.net/2318/63598

since

Published version:

DOI:10.1007/s11259-009-9254-z

Terms of use:

Open Access

Anyone can freely access the full text of works made available as "Open Access". Works made available under a Creative Commons license can be used according to the terms and conditions of said license. Use of all other works requires consent of the right holder (author or publisher) if not exempted from copyright protection by the applicable law. 


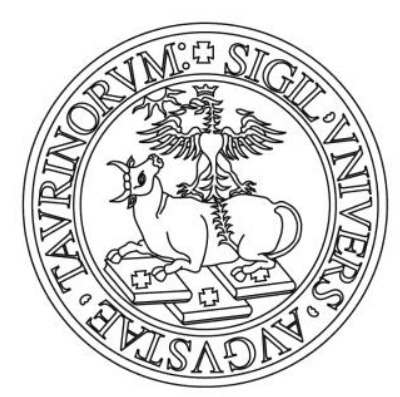

\section{UNIVERSITÀ DEGLI STUDI DI TORINO}

This is an author version of the contribution published on:

Neterinary Research Communications 2009; 33 (Suppl 1): pages S101-S103 Springer Ed]

The definitive version is available at:

La versione definitiva è disponibile alla URL:

[http://link.springer.com/article/10.1007\%2Fs11259-009-9254-z] 


\title{
Functional identification of bovine mammary epithelial stem/progenitor cells
}

\author{
E. Martignani, P. Eirew, C. Eaves, M. Baratta
}

\section{Introduction}

The lactation curve in dairy cattle has a well known pattern: after parturition, milk production rapidly increases with a maximum peak approximately a month later, then it slowly and steadily decreases. It has previously been shown that the initial increase in milk production is due to the growing secretory activity of alveolar epithelial cells. After the peak of lactation, there is no further change in the secretory activity and the following decline in milk production depends on a slow and continuous decrease in the number of secreting cells (Capuco et al. 2001). Strategies aimed at achieving higher milk production, like the administration of somatotropin, have been shown to be effective through their proliferative effect on epithelial cells in mid-late lactation (Capuco et al. 2003.). Thus, gaining control over mammary epithelial cell proliferation may prove to be a key point in increasing milk production in dairy cattle. In the mouse the existence of a subpopulation of adult stem cells residing in the mammary gland epithelium has been demonstrated (Shackleton et al. 2006; Stingl et al. 2006): these cells are able to regenerate an entire mammary gland in vivo and they have tremendous proliferative potential. To date, the existence of bovine adult stem cells has been only hypothesized (Ellis and Capuco 2002; Capuco 2007) and no functional assay is available to identify and characterize these cells in the bovine mammary gland.

\section{Materials and methods}

A single cell suspension was made from mammary tissue samples taken from a 7 month old Red Angus heifer by an initial enzymatic digestion with collagenase and hyaluronidase followed by treatment with trypsin, dispase and DNAse I. To perform the colony forming cell assay 5x 10 cells were seeded on collagen-coated $60 \mathrm{~mm}$ tissue culture dishes along with 2x1O6 murine fibroblasts (NIH 3 T3) previously irradiated at $60 \mathrm{~Gy}$. The cells were cultured for 7-9 days in EpiCult $\mathrm{B}$ medium at $37^{\circ} \mathrm{C}$ and $5 \% \mathrm{CO} 2$ and then fixed with methanol/acetone (1:1). The xenografts were carried out by resuspending 7.5 xlO4 bovine mammary epithelial cells and 1.6xlO5 murine $10 \mathrm{~T} 1 / 2$ fibroblasts irradiated at 15 Gy in collagen. The gels were then surgically implanted under the kidney capsule of immunodeficient NOD/SCID-IL2Ryc"" as described (Parmar et al. 2002). After 3 and 4 weeks the gels were recovered and they were either fixed in a $10 \%$ neutral buffered formalin solution (Fisher) and processed for histological and immunohis-tological analysis, or enzymatically dissociated and the cells used to perform a CFC assay. Antibodies against cytokeratin 18 (Sigma), cytokeratin 14 (Covance), alpha smooth muscle actin (DAKO) and cytokeratin 19 (R\&D System) were used for immunohistochemical staining. Colonies obtained in the CFC assay were incubated with these antibodies and stained using the Ultravision I kit (Lab Vision Corporation) according to the manufacturer's instructions. Tissue sections cut off the xenografts were immunologically stained with the same protocol and then countercoloured with ematoxylin (Sigma). Where not specified, reagents were purchased from Stem Cell Technologies.

\section{Results}

The in vitro assay to detect the colony-forming capability of mammary cells (CFC assay) showed that when cells were seeded at clonal density, colonies were detected after just $4-5$ days with an approximate frequency of $10 \%$ (number of colonies over total cells seeded). Three types of colony were observed and classified (types A, B and C) according to the size of the colony and morphology of the cells. Colonies were also characterized according to the expression of markers specific for two different subpopulations of mammary epithelial cells: luminal (CK18 and CK19) and myoepithelial (CK14). Particularly, type A colonies have a myoepithelial phenotype (CK18 and CK14+), while B and C colonies have a luminal phenotype (CK18+, CK14 ). In order to identify cells with morphogenic capabilities and higher proliferative potential, xenografts were carried out in immunodeficient mice: both after 3 and 4 weeks spherical-shaped structures that were organized in a double layer and containing an internal lumen could be detected. Immunohistochemical staining of the xenograft sections revealed that all the cells of the outer layer were CK14+, $\alpha$-SMA+ and CK18 while only a few cells were CK19+. On the contrary cells of the inner layer were CK14, a-SMA and CK19+. Some of the structures included cells of the inner layer weakly positive to CK18. CFC assays performed on cells recovered from some xenografts had the same three types of colonies as detected by morphological and immunohistological data.

\section{Discussion}

Human mammary epithelial progenitor cells are a non-terminally differentiated population that retains a limited proliferative potential and the ability to form colonies if cultured in vitro. This property allows their identification in a CFC assay as previously described (Stingl et al. 2001). The data presented in this work support the hypothesis that similar cells exist in the bovine mammary gland and that the CFC assay could also be adopted for bovine epithelial cells too. The different colony morphologies suggest the existence of different progenitor populations, each one with a limited differentiation capability. The xenograft technique was originally set up for human mammary cells (Parmar et al. 2002) and we show here that the same approach could be used to identify bovine mammary epithelial cells with the ability to 
form organized structures in vivo and to generate progenitor cells. This evidence suggests the existence of a tissue hierarchy in the bovine mammary gland similar to the human one. These results can be considered a starting point to achieve a better understanding of the mechanisms and the factors that induce the proliferation and differentiation of the progenitors/stem cells compartment in the bovine mammary gland.

Acknowledgements This research was supported by grants from University of Torino 2007 and Ricerca Sanitaria Regione Piemonte 2007.

\section{References}

Capuco A.V., 2007. Identification of putative bovine mammary epithelial stem cells by their retention of labeled DNA strands. Experimental Biology and Medicine (Maywood), 232(10), 1381-1390.

Capuco A.V., Wood D.L., Baldwin R., Mcleod K., Paape M.J., 2001. Mammary cell number, proliferation, and apoptosis during a bovine lactation: relation to milk production and effect of bST. Journal of Dairy

Science, 84(10), 2177-2187.

Capuco A.V., Ellis S.E., Hale S.A., Long E., Erdman R.A., Zhao X., Paape M.J., 2003. Lactation persistency: insights from mammary cell proliferation studies. Journal of Animal Science, 81(Suppl. 3), 18-31.

Ellis S. and Capuco A.V., 2002. Cell proliferation in bovine mammary epithelium: identification of the primary proliferative cell population. Tissue \& Cell, 34(3), 155-163.

Parmar H., Young P., Emerman J.T., Neve R.M., Dairkee S., Cunha G.R., 2002. A novel method for growing human breast epithelium in vivo using mouse and human mammary fibroblasts. Endocrinology, 143(12), $4886^{\wedge} 896$.

Shackleton M., Vaillant F., Simpson K.J., Stingl J., Smyth G.K., Asselin-Labat M.L., Wu L., Lindeman G.J., Visvader J.E., 2006. Generation of a functional mammary gland from a single stem cell. Nature, 439 (7072), 84-88.

Stingl J., Eaves C.J., Zandieh I., Emerman J.T., 2001. Characterization of bipotent mammary epithelial progenitor cells in normal adult human breast tissue. Breast Cancer Research and Treatment, 67(2), 93 109.

Stingl J., Eirew P., Ricketson I., Shackleton M., Vaillant F., Choi D., Li H.I., Eaves C.J., 2006. Purification and unique properties of mammary epithelial stem cells. Nature, 439(7079), 993-997. 